特発性栓球減少性紫斑病の本態に関する

臨床的亚びに実験的研究

\author{
第 2 編 \\ 骨髄巨核球機能飞及ぼす実験的栓球減少症 \\ 海猽血清の影響に就いて \\ 岡山大学医学部平木内科（主任：平木 潔教授） \\ 本多正憲
}

〔昭和 34 年 3 月 2 日受稿〕

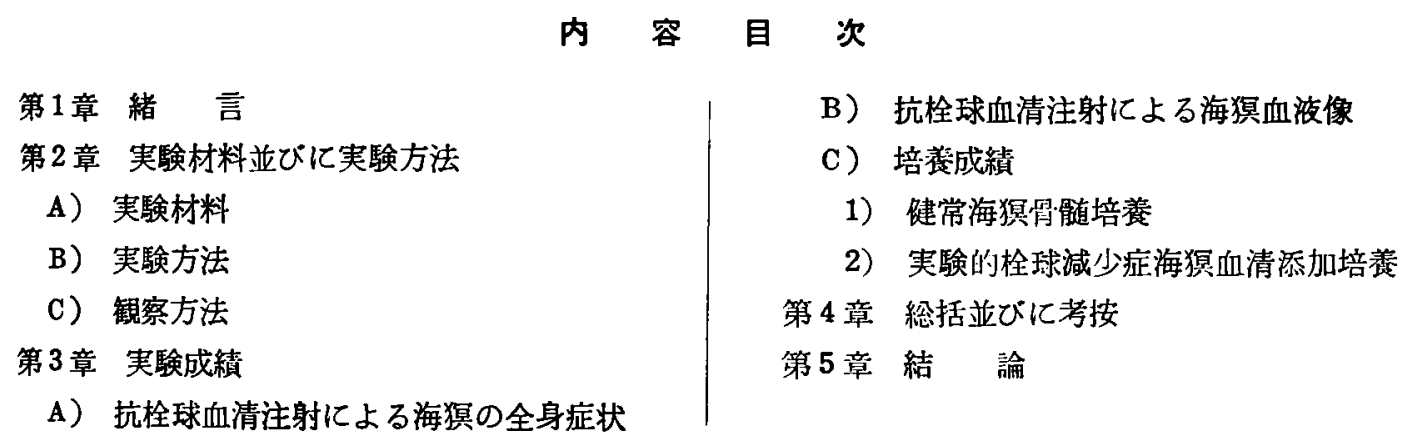

\section{第 1 章 緒言}

人の特発性栓球减少性热病の本態阔しては, 従来より多くの説がなされており, 就中栓球减少は 最も重視されているが，その所以についても患者血 清中や，患者脾中に催拴球減少性因子が証明されて いる，更に剔脾，ACTH，Cortison 等により本症 か治管するととから，本症の病因として，他の種々 の要因が主張されている．而して，本症患者胃随内 に於いて，栓球の母細胞である骨随巨核球に，形菂 学的，機能的障碍のある事は， F rank2)(1915）以来， 多くの学者によつて確認されて来た。私も，前編に 於いて，健康人骨喵道に，本症患者血清を添加培意す ろ事によつて，血清中に巨核球機能減弱を苍起する 因子の存在する事を証明し，報告した．

以上の如く，臨床的に栓球減少症之出血性絭因の 関保汃次第に明らかにされ，栓球減少の成因に関し て多くの研究が行なわれる一方，動物について，実 的侸栓球減少症を発現せしめて, その栓球減少の 本想に関して種々の検討がなされて来ている. 就中 Ledingham 54 ) (1914）の抗海猽栓球血清注射による
動物の実験的紫斑病の報告を始めとして，免疫血液 学的方面よりする研究は甚だ多い. 而して, その何 れ屯が，抗栓球血清注射が，栓球の減少，出血性素 因の発来を見る事を確認し，その発現機序を，各々 独自の立場より説明せんとしているが，未だ定説を 得ない。

私む海娦に抗栓球血清を注射して, 奏跧的栓球減 少症を発現せしめ, 教室考案の簡易骨骮組織培羡法 を用いて，その栓球減少の成因を明らかにし，人の 特発性栓球減少性紫琣病之比較検討する目的で塞験 を行なつた，その結果, 実験的栓球減少症動物の血 清中にむ，人の特発性栓球減少性紫理病患者血清之 同樣，直接骨随巨核球化作用する因子の存在する事 を確かめたのでここに報告して，諸監の御批判を仰 ぎたいと思う.

\section{第 2 章 実験材料並ひに実験方法}
A） 実験材料

1）体重 300 瓦前後の趾常海猽

2）体重 2 昕前後の觧常家兔 
B）実験方法

1）抗栓球血清の製法

i）栓球の分游

綿引氏55)，川野氏56）の方法を基焂化，若干の改 変を加えた方法で海猽の栓球を分離した。 即ち, 予 めシリコン・コーテイングを施した注射器に3.8\% クエン酸ソーダ溶液を取り，心臟穿刺により，数匹 の健常海猽より採血し, 約 $30 \mathrm{cc}$ に及ふ。. 次いで, 予めシリコン・コーティングを施した遠沈管に之を 取り，每分2000回転，約10分間遠心滩して赤血球， 白血球を沈激せしめ，上部のやや黄白色を帯びた上.

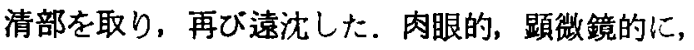
赤血球，白血球の残存していない事を確認してから， 生理的食塩水にて洗浄，強〈遠沈して栓球を分離し た。この洗净，遠沈の操作を 3 回ほど繰返す事によ

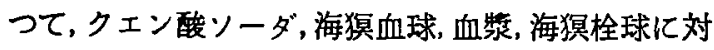
する抗体が産生される。斯様にして線維素は全て除 加，純柈に海狽栓球の生理的食塩水浮遊液を得る。

1 回の約 $30 \mathrm{cc}$ の採血により得た栓球を， $3 \mathrm{cc} の$ 生理的食塩水に浮遊せしめ, 之を抗原として, 家兔 耳静脈注射した。

ii）免度操作

1 週間每に，海猽の栓球分離，家兔えの注射を繰 返して，6 週間に及ぶと，家兔血清中には，海犋栓 球に対する抗体が産生される. 斯様にして海獏栓球 により免疫された家克より，心㖑穿刺により採血し， 血清を分離して氷室中に眝え，機に臨んで使用した。

2）海犋に対する抗栓球血清の注射方法

上記の方法で得られた抗栓球血清を, 予め血液像 を検查した 300 瓦前後の㯬常海㩧の皮下に 0.7 $1.0 \mathrm{cc}$ 注射した。先蜸によれば，静脈内，腹腔内， 蜘蛛膜下等えの注射も試みられているか566)67)，発現 症状が過敨汇過ぎ，実験に不便を来すので，私は皮 下注射を選んだ. この注射を $2 \sim 3$ 日連続し，この 都度血液像を検查した。大凡 2 乃至 3 回の注射で， 海猽の多くは出血による二次的貫血，著明な栓球减 少を見, 皮下出血, 臟器出血等の出血性素因を米し, 大凡 3 回の注射によつて海㺍の大部分は整死した.

3）血清採取

実験的に栓球減少症を来した海㩧より，最初の注 射日を含めて 3 乃至 4 日目に，心臟穿刺によつて探 血, 遠沈して血清を得た. 対照としては, 栓球減少 のない坢常海猽の血清を使用した。

4) 骨喠培意

i）栓球減少のない㯬常海猽を媄殺し，大腿骨骨
㵦を予め乾熱㓕菌したシャーレ内に取つたリンゲル 氏液内に入れ，直ちに実験に用いた。

ii）教室考案の簡易骨䯣組織培羡法12）飞従い, 予め乾熟滅菌した薄手スライド・グラス上に，約 $2.5 \mathrm{~cm}$ の間隔で市販の張符貼紙 $(10 \mathrm{~mm} \times 20 \mathrm{~mm})$ を 3 枚宛貼付して高さ $600 \mu$ の土手を作つておき， その中央に, 奏験的栓球減少症海㺍の血清を 1 滴取 り, 硝子棒にて直徍 $1.5 \mathrm{~cm}$ の円形に拡ける. その 上に，先に取出した健常海狽骨鹃道の 1 片を置き，次 いでビタミン $B_{12}(1 \mathrm{cc}$ 中 $100 \gamma$ 含有) 注射液の 1 滴を滴下する. 予め洗浄, 乾熱隇菌した薄手か心゙ 一・グラス $(24 \mathrm{~mm} \times 32 \mathrm{~mm})$ で静か化掩い, 周囲 をパラフィンにて封し，瞬卵器 $\left(37^{\circ} \mathrm{C}\right)$ 内に静置す る. 対照として，健常海犋血清を用いた標本を同様 にして作製する．血清及びビタミン $\mathrm{B}_{12}$ 注射液は， ッベルクリン注射器に 1/2 針をつけたものを使用 して昰比を一定にした。

以上の諸操作は, 全く無菌的且つ迅速に行なつた。

C）観察方法

海犋骨髄の培養に於いても，人間のそれの場合と 同様に，培養 3 洔間比加ら，組織の著明な增生が見 られ，12 24時間後には，多くの標本に巨核球が出 現し，その運動形態を観察する事が出来る.

12，24，36時間の 3 回に亘つて, 標本を取り出し, 增生帯に遊出した巨核球の出現個数, 㖶動形態を钼 察した。

巨核球の連動形態を，次の 3 型に分つた。即

A 型 胞体の軽度変形を認めるもの

B 型 偽足形成のあるもの

C 型 触手状突起形成を認め，栓球分離を示する の

更に組織增生面積，好中球の遊走速度をアツベ氏 描画器を用いて指画測定した。

以上の観察は, 全て $37^{\circ} \mathrm{C}$ に保つた保温箱中に於 いて行なつた.

\section{第3章実 医 成 縝}

1）抗栓球血清注射による海獏の全身症状 1回 $0.7 \sim 1.0 \mathrm{cc}$ の抗栓球血清を揵常海㩧の皮下に 注射すると，早いむのでは注射の翌日死亡するもの がある．之を剖检すると，当該血清の最す多く消費 される注射部位に於いて，最も強い出血の起つてい る事は当然であるが，心，肺，肝，骂，大腸，大網， 腸間膜，皮下，皮赎等に広汎な出血巣を見，就中脾 腫の著明なむのも数例之を見た。 
培飬に用いた血清は，実験海犋のうち，血液像の 検査により，栓球減少著明，皮下出血が著明で且つ
死に䫀していないあのから採取して使用した。

2) 抗栓球血清注射による海猽血液像の変化

表 I 抗栓球血清注射海猽血液像

\begin{tabular}{|c|c|c|c|c|c|c|c|c|c|c|c|c|c|c|}
\hline \multirow[t]{4}{*}{$\begin{array}{l}\text { 海 } \\
\text { 㩧 } \\
\text { 番 } \\
\text { 号 }\end{array}$} & \multirow{4}{*}{ 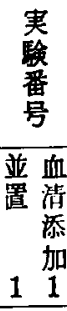 } & \multirow{4}{*}{$\begin{array}{l}\text { 血 } \\
\text { 薏 } \\
\text { 量名 } \\
94 \\
65 \\
63\end{array}$} & $\begin{array}{c}\text { 赤球 } \\
\text { 血数 } \\
\times 104\end{array}$ & $\begin{array}{l}\text { 白 } \\
\text { 血 } \\
\text { 球 } \\
\text { 数 }\end{array}$ & $\begin{array}{c}\text { 網血 } \\
\text { 㺴球 } \\
\text { 赤数 } \\
\% 0 \\
\%\end{array}$ & $\begin{array}{l}\text { 栓 } \\
\text { 球 } \\
\text { 数 }\end{array}$ & \multicolumn{3}{|c|}{ 白血球 百分率 } & & 今 率 & $\mathrm{Hi}$. & \multicolumn{2}{|c|}{ 備 } \\
\hline & & & 602 & 8,400 & 15 & 144,500 & 59.2 & 18.4 & 0 & 0.8 & 0.8 & 0.8 & 抗栓球血清 & \\
\hline & & & 410 & 12,000 & 40 & 24,600 & 42 & 51 & 6 & 1 & 0 & 0 & " & 0.7 \\
\hline & & & 390 & 11,800 & 46 & 15,600 & 37 & 61 & 1 & 1 & 0 & 0 & 显置培養 & 血清添加 \\
\hline \multirow{4}{*}{2} & \multirow{4}{*}{22} & 95 & 642 & 17,000 & 18 & 89,900 & 33 & 51 & 8 & 5 & 2 & 1 & A. P. S. & $0.7 \mathrm{cc}$ \\
\hline & & 68 & 312 & 16,800 & 18 & 21,800 & 43 & 51 & 6 & 0 & 0 & 0 & " & $0.5 \mathrm{cc}$ \\
\hline & & 30 & 131 & 24,400 & 20 & 18,300 & 38 & 47 & 3 & 2 & 0 & 0 & " & $0.5 c c$ \\
\hline & & 38 & 188 & 17,600 & 26 & 22,600 & 39 & 50 & 6 & 4 & 1 & 0 & 並置培養 & 血清添加 \\
\hline \multirow{4}{*}{3} & & 98 & 592 & 11,000 & 24 & 200,300 & 27 & 62 & 8 & 0 & 1 & 2 & A. P. S. & $0.5 \mathrm{cc}$ \\
\hline & & 105 & 554 & 17,600 & 18 & 22,200 & 34 & 55 & 7 & 3 & 1 & 0 & $"$ & $0.5 \mathrm{cc}$ \\
\hline & & 45 & 249 & 17,600 & 36 & 14,900 & 31 & 65 & 3 & 1 & 0 & 0 & $"$ & $0.5 \mathrm{cc}$ \\
\hline & & 73 & 252 & 14,000 & 54 & 15,100 & 38 & 56 & 3 & 2 & 1 & 0 & 失 & 死 \\
\hline \multirow{3}{*}{4} & & 105 & 607 & 16,000 & 22 & 378,000 & 31 & 58 & 7 & 3 & 0 & 1 & A. P. S. & $0.5 \mathrm{cc}$ \\
\hline & & 66 & 334 & 12,000 & 20 & 53,400 & 39 & 60 & 0 & 0 & 0 & 1 & $"$ & $0.5 \mathrm{cc}$ \\
\hline & & 35 & 152 & 13,400 & 46 & 15,200 & 40 & 56 & 2 & 1 & 1 & 0 & 失 & 死 \\
\hline \multirow{3}{*}{5} & & 100 & 506 & 17,800 & 18 & 540,000 & 29 & 63 & 5 & 1 & 0 & 1 & A. P.S. & $0.5 c c$ \\
\hline & & 64 & 403 & 24,000 & 22 & 11,500 & 32 & 63 & 3 & 0 & 1 & 0 & " & $0.5 \mathrm{cc}$ \\
\hline & & 30 & 192 & 18,000 & 58 & 3,000 & 26 & 71 & 1 & 1 & 1 & 0 & 失 & 死 \\
\hline \multirow{3}{*}{6} & \multirow{3}{*}{3} & 98 & 537 & 18,600 & 18 & 196,000 & 43 & 55 & 0 & 1 & 0 & 1 & A. P. S. & $0.5 c c$ \\
\hline & & 62 & 323 & 13,200 & 20 & 25,800 & 35 & 62 & 1 & 1 & 1 & 0 & $" 1$ & $0.5 \mathrm{cc}$ \\
\hline & & & & & & & & & & & & & 血 & 添 加 \\
\hline \multirow[t]{2}{*}{7} & & 87 & 497 & 7,400 & 18 & 89,500 & & & & & & & A.P.S. & $0.5 \mathrm{cc}$ \\
\hline & & 78 & 375 & 12,000 & 16 & 15,000 & & & & & & & 失 & 死 \\
\hline \multirow{4}{*}{8} & & 100 & 555 & 10,600 & 7 & 180,000 & 42 & 49 & 6 & 3 & 0 & 0 & A. P. S. & $0.5 \mathrm{cc}$ \\
\hline & & 88 & 510 & 15,800 & 7 & 40,800 & 33 & 53 & 8 & 4 & 1 & 1 & " & $0.5 c c$ \\
\hline & & 65 & 383 & 12,000 & 9 & 7,700 & 45 & 47 & 6 & 1 & 0 & 1 & " & $0.5 c c$ \\
\hline & & & & & & & & & & & & & 失 & 死 \\
\hline \multirow{5}{*}{9} & & 108 & 604 & 6,800 & 16 & 85,600 & 28 & 63 & 6 & 3 & 0 & 0 & A. P.S. & $0.5 \mathrm{cc}$ 注 \\
\hline & & 85 & 461 & 7,400 & 10 & 36,900 & 43 & 52 & 3 & 1 & 1 & 0 & $"$ & $0.5 c c$ \\
\hline & & 50 & 338 & 8,000 & 20 & 6,800 & 47 & 45 & 3 & 3 & 1 & 1 & " & $0.5 \mathrm{cc}$ \\
\hline & 34 & & & & & & & & & & & & 血＼cjkstart清 & 添 加 \\
\hline & & & & & & & & & & & & & 业 & क \\
\hline \multirow{4}{*}{10} & & 98 & 500 & 9,800 & 16 & 334,000 & 39 & 55 & 3 & 2 & 1 & 0 & A. P. S. & $0.7 \mathrm{cc}$ \\
\hline & & 87 & 434 & 10,200 & 25 & 46,000 & 41 & 52 & 2 & 2 & 3 & 0 & " & $0.7 \mathrm{cc}$ \\
\hline & & 72 & 360 & 12,000 & 41 & 10,800 & 52 & 44 & 1 & 1 & 2 & 0 & " & $0.7 \mathrm{cc}$ \\
\hline & 40 & 68 & 350 & 14,100 & 43 & 3,500 & 51 & 39 & 5 & 3 & 1 & 1 & 並圆培養 & 血清添加 \\
\hline \multirow{3}{*}{11} & \multirow{3}{*}{56} & 103 & 511 & 9,200 & 7 & 623,000 & 48 & 48 & 2 & 1 & 1 & 0 & A. P. S. & $0.8 \mathrm{cc}$ \\
\hline & & 87 & 450 & 10,300 & 13 & 59,600 & 39 & 58 & 1 & 1 & 1 & 0 & " & $0.7 \mathrm{cc}$ \\
\hline & & 64 & 340 & 12,200 & 37 & 6,800 & 37 & 59 & 1 & 2 & 1 & 0 & 並圆培羡 & 血清添加 \\
\hline
\end{tabular}




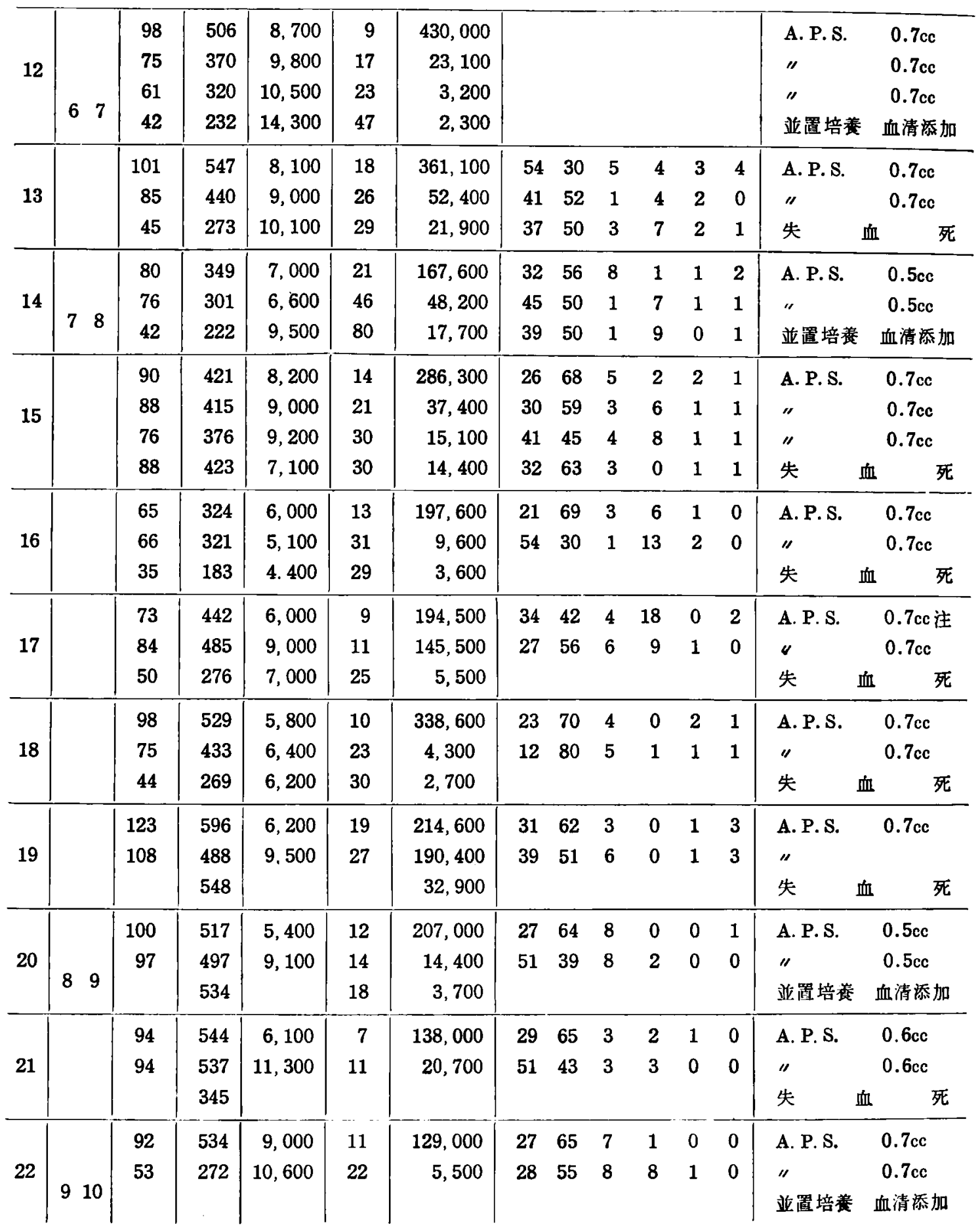

表 I 亿見る如く，各例とも 1 万至 2 回の抗栓球血 清注射により，二次的貧血の像を示し，網状赤血球の 增多, 軽度の白血球の增多，栓球の著しい減少（約 1/2 1/10）が認められ，白血球百分率では，好中 球，好酸球の柽度の增少の見られるものが多かつた。 出血時間の測定は行なわなかつたが，耳桑よりの出 血の非常に停止し嚾い所から，その延長のある娶は 疑いない，消栓球数の算定には一Fonio 氏原法に森
田氏法58）を併用し，マイ・ギムザ染色を施す間接 法汇拠つた。

3）培棌成緽

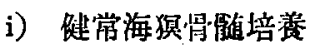

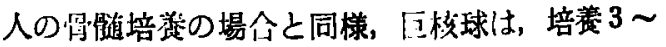
6 侍間後でる增生帯に出現し，観察可能であるが， この数も非常に少ないので，二の運動形態を稫察す るには，人の場合と同様12〜24時間後が最適であつ 
t.

図I．表II（No. 1 10）に見る如く，増生帯に 出現する巨核球数は，培䍲 12 㭙間後 $3.2 \sim 12.5$ 個，

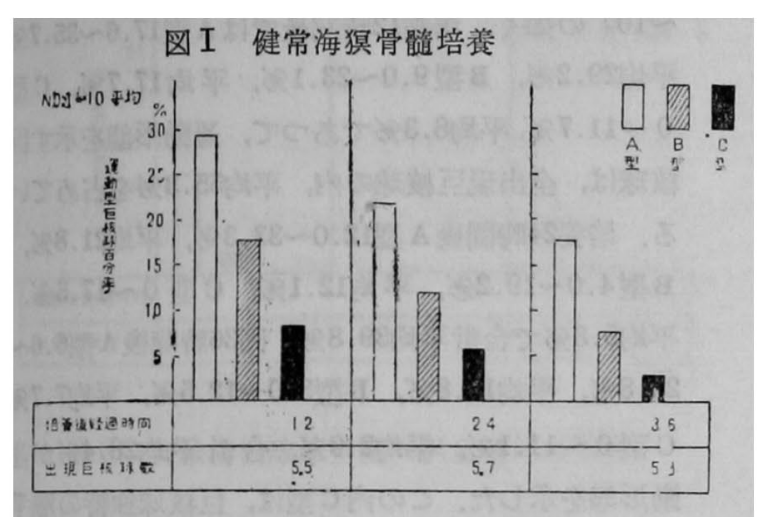

表II 健常海犋骨髓培養

No. 1

\begin{tabular}{|c|c|c|c|c|c|c|}
\hline \multicolumn{4}{|c|}{ ○培養後经過時間 } & 12 & 24 & 36 \\
\hline \multicolumn{4}{|c|}{ 出現巨核球 数 } & 12.5 & 11.4 & 11.4 \\
\hline \multirow{4}{*}{$\begin{array}{l}\text { 遭球 } \\
\text { 娌百 } \\
\text { 型分 } \\
\text { 核 }\end{array}$} & & 型 & 96 & 21.3 & 24.6 & 22.2 \\
\hline & B & 型 & $\not 6$ & 18.6 & 8.8 & 6.7 \\
\hline & C & 型 & 9 & 6.6 & 17.5 & 11.1 \\
\hline & & 計 & $\not 6$ & 46.5 & 50.9 & 40.0 \\
\hline \multirow{2}{*}{\multicolumn{4}{|c|}{$\begin{array}{c}\text { 比 较 成 長 価 } \\
\text { 好中球遊走速度 } \mu / \mathrm{min}\end{array}$}} & 14.41 & 20.85 & ノ \\
\hline & & & & 4.87 & 3.15 & ノ \\
\hline
\end{tabular}

No. 2

\begin{tabular}{|c|c|c|c|c|c|c|}
\hline \multicolumn{4}{|c|}{ 培養後経過時間 } & 12 & 24 & 36 \\
\hline \multicolumn{4}{|c|}{ 出現巨核 球 数 } & 5.6 & 4.6 & 5.0 \\
\hline \multirow{4}{*}{ 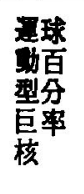 } & $\mathbf{A}$ & 型 & $\mathscr{0}$ & 33.3 & 22.2 & 19.8 \\
\hline & B & 型 & 96 & 22.2 & 11.1 & 8.9 \\
\hline & $\mathbf{C}$ & 型 & 90 & 11.1 & 11.1 & 0 \\
\hline & & 計 & 96 & 66.6 & 44.4 & 28.7 \\
\hline \multirow{2}{*}{\multicolumn{4}{|c|}{$\begin{array}{c}\text { 比 较 龙 長 価 } \\
\text { 好中球遊走速度 } \mu / \mathrm{min}\end{array}$}} & 9.82 & 15.00 & I \\
\hline & & & & 3.24 & 2.84 & / \\
\hline
\end{tabular}

No. 3

\begin{tabular}{|c|c|c|c|c|c|c|}
\hline \multicolumn{4}{|c|}{ 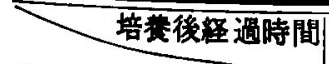 } & \multirow{2}{*}{$\frac{12}{4.5}$} & \multirow{2}{*}{$\frac{24}{5.0}$} & \multirow{2}{*}{$\begin{array}{r}36 \\
5.0\end{array}$} \\
\hline 出現 & 巨核 & 矢球 & 数 & & & \\
\hline \multirow{4}{*}{$\begin{array}{l}\text { 運球 } \\
\text { 地百 } \\
\text { 型分 } \\
\text { 慗 } \\
\text { 核 }\end{array}$} & A & 型 & 96 & 17.6 & 21.4 & 6.6 \\
\hline & B & 型 & 96 & 17.6 & 14.3 & 6.6 \\
\hline & $\mathrm{C}$ & 型 & $\%$ & 11.7 & 0 & 0 \\
\hline & & 計 & 96 & 47.0 & 35.7 & 13.3 \\
\hline & 成 & 長 & 価 & 15.04 & 16.04 & I \\
\hline 好中球 & 走速 & 度, & $\min$ & 3.25 & 1.88 & $/$ \\
\hline
\end{tabular}

No. 4

\begin{tabular}{|c|c|c|c|c|c|c|}
\hline \multicolumn{4}{|c|}{ 培美後経過恃間 } & 12 & 24 & 36 \\
\hline \multicolumn{4}{|c|}{ 出現巨核球数 } & 3.6 & 4.0 & 4.2 \\
\hline \multirow{4}{*}{$\begin{array}{l}\text { 運 } \\
\text { 動球 } \\
\text { 型百 } \\
\text { 夏分 } \\
\text { 核率 }\end{array}$} & & 型 & $\mathscr{b}$ & 35.7 & 18.3 & 18.3 \\
\hline & & 型 & $\not 6$ & 21.4 & 11.1 & 6.6 \\
\hline & $\mathbf{C}$ & 型 & 96 & 10.0 & 0.3 & 0 \\
\hline & & 計 & 9 & 67.1 & 29.7 & 24.9 \\
\hline 比 1 & 成 & 長 & 価 & 8.46 & 11.33 & l \\
\hline \multicolumn{4}{|c|}{ 好中球逊走速度 $\mu / \mathrm{min}$} & 5.88 & 2.41 & 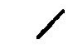 \\
\hline
\end{tabular}

No. 5

\begin{tabular}{|c|c|c|c|c|}
\hline \multicolumn{2}{|c|}{ 培養後経過時間 } & 12 & 24 & 36 \\
\hline \multicolumn{2}{|c|}{ 出現巨核 球 数 } & 7.8 & 8.0 & 8.0 \\
\hline \multirow{4}{*}{ 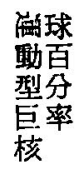 } & A 型 $\mathscr{6}$ & 33.3 & 22.2 & 11.1 \\
\hline & B 型 $\mathscr{6}$ & $1 \Sigma .5$ & 11.0 & 5.5 \\
\hline & C 型 96 & 8.3 & 5.5 & 2.8 \\
\hline & 合 計 $\mathscr{q}$ & 54.1 & 38.8 & 16.7 \\
\hline \multirow{2}{*}{\multicolumn{2}{|c|}{$\begin{array}{c}\text { 比 较 成 层 価 } \\
\text { 好中球遊走速度 } \mu / \mathrm{min}\end{array}$}} & 9.02 & 14.38 & I \\
\hline & & 5.36 & 2.28 & $\gamma$ \\
\hline
\end{tabular}

No. 6

\begin{tabular}{|c|c|c|c|c|c|c|}
\hline \multicolumn{4}{|c|}{ 二 培喽後経過時間 } & 12 & 24 & 36 \\
\hline \multicolumn{4}{|c|}{ 出現巨核 球 数 } & 4.3 & 4.5 & 4.2 \\
\hline \multirow{4}{*}{$\begin{array}{l}\text { 運球 } \\
\text { 動香 } \\
\text { 型率 } \\
\text { 核 }\end{array}$} & $\mathbf{A}$ & 型 & $\%$ & 29.9 & 11.4 & 15.4 \\
\hline & B & 型 & 96 & 16.8 & 19.2 & 7.6 \\
\hline & C & 型 & 96 & 10.1 & 7.7 & 3.8 \\
\hline & & 計 & $\%$ & 56.8 & 38.3 & 26.9 \\
\hline 比 & 成 & 長 & 価 & 7.35 & 13.16 & I \\
\hline 好中球 & 走速 & $\mathbb{Z} \mathbb{Z} \mu$ & $\min$ & 4.44 & 1.92 & / \\
\hline
\end{tabular}

No. 7

\begin{tabular}{|c|c|c|c|c|c|c|}
\hline \multicolumn{4}{|c|}{ 人培挙後経過㭙間 } & 12 & 24 & 36 \\
\hline \multicolumn{4}{|c|}{ 出現巨檬球 数 } & 4.5 & 5.0 & 4.5 \\
\hline \multirow{4}{*}{$\begin{array}{l}\text { 運球 } \\
\text { 動百 } \\
\text { 型分 } \\
\text { 孝 } \\
\text { 核 }\end{array}$} & & 型 & 96 & 34.4 & 22.2 & 26.8 \\
\hline & & 型 & 96 & 23.1 & 14.8 & 11.1 \\
\hline & $\mathbf{C}$ & 型 & 96 & 6.7 & 7.4 & 3.5 \\
\hline & & & 96 & 64.2 & 44.4 & 40.7 \\
\hline \multirow{2}{*}{\multicolumn{4}{|c|}{$\begin{array}{l}\text { 比 较 成 坛 価 } \\
\text { 好中球遊走速度 } \mu / \mathrm{min}\end{array}$}} & 7.41 & 12.59 & / \\
\hline & & & & 6.32 & 2.30 & $\gamma$ \\
\hline
\end{tabular}


No. 8

\begin{tabular}{|c|c|c|c|c|c|c|}
\hline \multicolumn{4}{|c|}{ 培羕後経過時間 } & \multirow{2}{*}{$\frac{12}{5.0}$} & \multirow{2}{*}{$\frac{24}{5.5}$} & \multirow{2}{*}{$\begin{array}{r}36 \\
5.5\end{array}$} \\
\hline 出 現 & 巨柆 & 球 & 数 & & & \\
\hline \multirow{4}{*}{$\begin{array}{l}\text { 運球 } \\
\text { 㔠臬 } \\
\text { 型分 } \\
\text { 核 }\end{array}$} & $\mathbf{A}$ & 型 & $\%$ & 33.3 & 12.0 & 15.0 \\
\hline & $\mathbf{B}$ & 型 & $\%$ & 9.0 & 4.0 & 3.0 \\
\hline & $\mathbf{C}$ & 型 & 96 & 0 & 2.0 & 2.0 \\
\hline & & 計 & 9 & 42.3 & 18.0 & 21.0 \\
\hline 比本 & 成 & 長 & 価 & 6.63 & 9.86 & 1 \\
\hline 好中球 & 走速 & F & $\min$ & 5.38 & 1.89 & $\gamma$ \\
\hline
\end{tabular}

No. 9

\begin{tabular}{|c|c|c|c|c|c|c|}
\hline \multicolumn{4}{|c|}{ 培養後経過時間 } & 12 & 24 & 36 \\
\hline \multicolumn{4}{|c|}{ 出現巨核 球 数 } & 3.2 & 4.6 & 5.0 \\
\hline \multirow{4}{*}{ 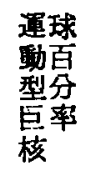 } & $\mathbf{A}$ & 型 & 96 & 23.4 & 31.2 & 25.0 \\
\hline & B & 型 & 96 & 18.7 & 18.7 & 12.5 \\
\hline & C & 型 & 96 & 11.7 & 6.3 & 6.3 \\
\hline & & 計 & 96 & 53.8 & 56.2 & 43.7 \\
\hline 比 & 成 & 長 & 価 & 9.43 & 17.11 & I \\
\hline 好中球 & 走速 & 度 $\mu$, & $\min$ & 4.20 & 1.98 & l \\
\hline
\end{tabular}

No. 10

\begin{tabular}{|c|c|c|c|c|c|c|}
\hline \multicolumn{4}{|c|}{ 一培養後経過時間 } & 12 & 24 & 36 \\
\hline \multicolumn{4}{|c|}{ 出現巨核 球 数 } & 4.0 & 4.5 & 4.5 \\
\hline \multirow{4}{*}{$\begin{array}{l}\text { 運球 } \\
\text { 動 } \\
\text { 型分 } \\
\text { 婆 } \\
\text { 核 }\end{array}$} & $\mathbf{A}$ & 型 & $\%$ & 30.0 & 33.3 & 16.7 \\
\hline & B & 型 & 96 & 17.5 & 8.3 & 8.3 \\
\hline & $\mathrm{C}$ & 型 & 96 & 7.5 & 0 & 0 \\
\hline & & 計 & $\%$ & 55.0 & 41.6 & 25.0 \\
\hline \multirow{2}{*}{$\begin{array}{c}\text { 比 } \\
\text { 好中球 }\end{array}$} & 成 & 長 & 価 & 10.18 & 16.70 & Y \\
\hline & 走速 & 底 & $\operatorname{nin}$ & 4.44 & 2.12 & / \\
\hline
\end{tabular}

表 $1^{\prime}$ No. $1 \sim 10$ 平均

\begin{tabular}{|c|c|c|c|c|c|c|}
\hline \multicolumn{4}{|c|}{ 7培養後経過時間 } & 12 & 24 & 36 \\
\hline \multicolumn{4}{|c|}{ 出現巨核球数 } & 5.5 & 5.7 & 5.8 \\
\hline \multirow{4}{*}{$\begin{array}{l}\text { 運球 } \\
\text { 動百 } \\
\text { 型分 } \\
\text { 萃 } \\
\text { 核 }\end{array}$} & $\mathbf{A}$ & 型 & 96 & 29.2 & 21.8 & 17.8 \\
\hline & & 型 & 96 & 17.7 & 12.1 & 7.7 \\
\hline & $\mathrm{C}$ & 型 & 96 & 8.3 & 5.8 & 2.9 \\
\hline & & 計 & 96 & 55.3 & 39.8 & 28.4 \\
\hline & & & & 9.78 & 14.70 & I \\
\hline \multicolumn{4}{|c|}{ 好中球遊走速度 $\mu / \mathrm{min}$} & 4.74 & 2.28 & ／ \\
\hline
\end{tabular}

平均5.5個，同24時間後 4.5 11.4個，平均5.7個， 同36時間後4.2 11.4個平均5.8個であつた。

次に，その運動形態を見るに，図 I．表II（No. 1 １0）の如く，培盖12時間後では $\mathrm{A}$ 型17.6 35.7\%， 平均 $29.2 \%, \mathrm{~B}$ 型9.0 23.1\%, 平均 $17.7 \%, \mathrm{C}$ 型 $0 \sim 11.7 \%$, 平均 $8.3 \%$ あっって, 運動形態を示す巨 核球は, 全出現巨核球の内, 平均55.3\%を占めてい る. 培養24時間後 $\mathrm{A}$ 型12.0 33.3\%，平均21.8\%， B 型4.0 19.2\%, 平均12.1\%, C 型 $0 \sim 17.5 \%$, 平均 $5.8 \%$ で合計平均 $39.8 \%$, 同36時間後 $\mathrm{A}$ 型6.6 26.8\%, 平均 $17.8 \%, B$ 型3.0 12.5\%, 平均7.7\%, $\mathrm{C}$ 型 $0 \sim 11.1 \%$, 平均 $2.9 \%$, 合計平均 $28.4 \%$ 公運 動形態を示した．乙の内 $\mathrm{C}$ 型は，巨核球独特の触手 状突起形成があり，時にその先端よりの栓球分離像 が見られた。 B 型も偽足形成が著明であつて， C 型 巨核球えの前段階と見られ，A型は，B型えの前段 階と見られる事は，人の骨䯣巨核球の場合と全く同 様であり，海犋巨核球運動形態の多少は，その栓球 形成の多少之関聯のある事は疑いない.

次に，骨䯣原組織よりの組織増生の比較成長価を 見るに，健康海㩧血清及び，ビタミン $\mathrm{B}_{12}$ 溶洨を 培地として，人の骨髄組織培養の場合と同様の增生 を示した。その值は，培褯12時間後6.63 15.04， 平均9.78，24時間後 9.86 20.85，平均14.70であつ て，健康人のそれとさしたる差異がなかつた，次い で増生帯に出現せる好中球の遊走速度を見るに，培 佘12時間後 $3.24 \sim 6.32 \mu / \mathrm{min}$ 平均 $4.74 \mu / \mathrm{min}, 24$ 時間後 $1.92 \sim 3.15 \mu / \mathrm{min}$ 平均 $2.28 \mu / \mathrm{min}$ であつ て，硉康人の場合に比し，低値を示した（図I，UI. 表II).

ii） 実験的栓球隇少症海㗄血清添加培童

実験的に栓球減少症を発現さしめた海倶の血清が， 巨核球に及に゙す影響を知る目的で，主）に行なつた と同様にして，健常海犋血清の代りに当該血清を用 いて趾常海洖骨随を培養して，i）と同様の観察を 行なつた。

图II. 表亚(No. 1 10）に見る如く，增生帯に出

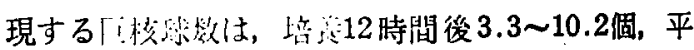
均5.9個，全24㭙間俊 $3.5 \sim 11.0$ 個，平均5.0個，同 36時間後3.8 10.8個，可均6.1個であつた，運動形 隹を示す核球を時間の推矽と共に追求すると，图

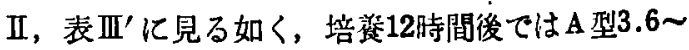
$23.8 \%$ ，平均 $11.3 \%$, B 型 $0 \sim 16.6 \%$, 平均 $2.31 \%$ ， $\mathrm{C}$ 型 0 １.2\%，平均0.1\%であつて，運動形热を示 す巨核球は，全出現巨核球の平均13.8\%であつた。 


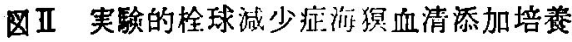

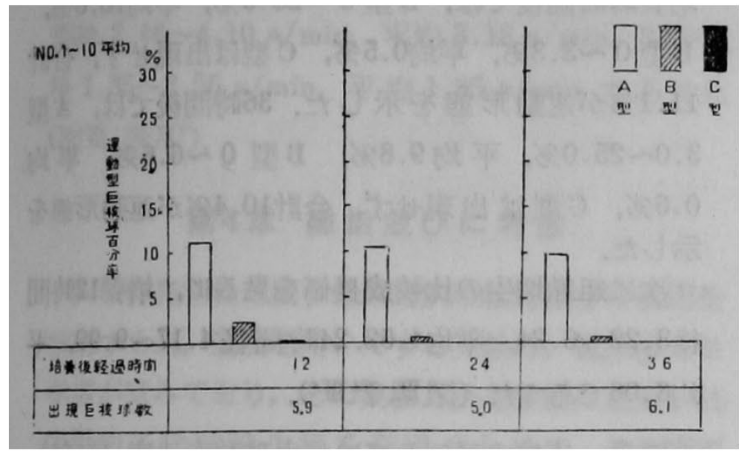

表II 実験的栓球隇少症海猽血清添加培注

No. 1

\begin{tabular}{|c|c|c|c|c|c|c|}
\hline \multicolumn{4}{|c|}{ 一 培春後経過時間 } & 12 & 24 & 36 \\
\hline \multicolumn{4}{|c|}{ 出現巨核球数 } & 8.8 & 7.0 & 7.3 \\
\hline \multirow{4}{*}{ 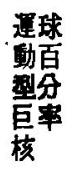 } & $\mathbf{A}$ & 型 & $\mathscr{6}$ & 23.0 & 28.5 & 10.3 \\
\hline & B & 型 & $\not 6$ & 0 & 0 & 0 \\
\hline & $\mathbf{C}$ & 型 & $\not 6$ & 0 & $\mathbf{0}$ & 0 \\
\hline & & 計 & $\%$ & 23.0 & 28.5 & 10.3 \\
\hline 比 & 成 & 長 & 価 & 5.39 & 6.69 & l \\
\hline 好中球 & 走速 & 年 & $\min$ & 3.88 & 2.55 & $\ell$ \\
\hline
\end{tabular}

No. 2

\begin{tabular}{|c|c|c|c|c|c|c|}
\hline \multicolumn{4}{|c|}{ 工培養後経過封間 } & 12 & 24 & 36 \\
\hline \multicolumn{4}{|c|}{ 出現巨核球 数 } & 5.0 & 4.8 & 4.0 \\
\hline \multirow{4}{*}{ 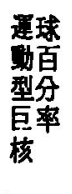 } & $\mathbf{A}$ & 型 & $\mathscr{6}$ & 10.0 & 0 & 25.0 \\
\hline & B & 型 & 96 & 0 & 0 & 0 \\
\hline & $\mathrm{C}$ & 型 & $\$ 6$ & 0 & 0 & 0 \\
\hline & & 計 & 96 & 10.0 & 0 & 25.0 \\
\hline \multirow{2}{*}{\multicolumn{4}{|c|}{$\begin{array}{c}\text { 比较 成 長 価 } \\
\text { 好中球遊走速度 } \mu / \mathrm{min}\end{array}$}} & 6.24 & 9.99 & \\
\hline & & & & 2.62 & 2.26 & \\
\hline
\end{tabular}

No. 3

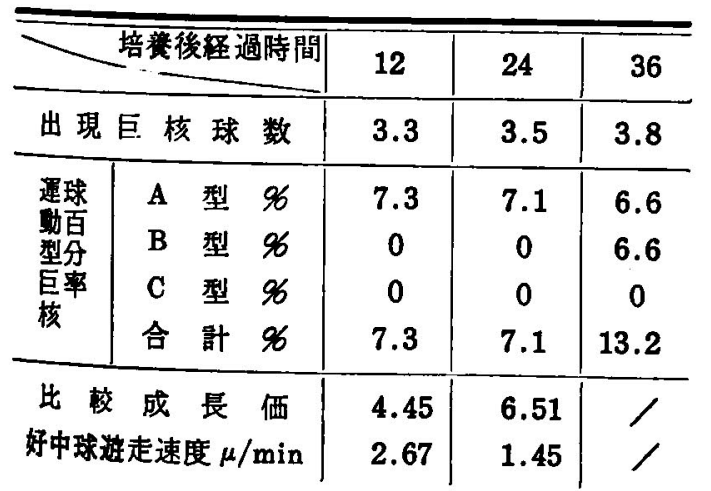

No. 4

\begin{tabular}{|c|c|c|c|c|c|c|}
\hline \multicolumn{4}{|c|}{ 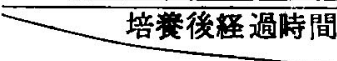 } & 12 & 24 & 36 \\
\hline \multicolumn{4}{|c|}{ 出現巨核 球 数 } & 6.0 & 6.3 & 6.3 \\
\hline \multirow{4}{*}{$\begin{array}{l}\text { 運球 } \\
\text { 動面 } \\
\text { 型率 }\end{array}$} & A & 型 & 96 & 16.6 & 16.0 & 12.0 \\
\hline & B & 型 & क & 16.6 & 0 & 0 \\
\hline & C & 型 & 96 & 0 & 0 & 0 \\
\hline & & 計 & $\mathscr{6}$ & 33.3 & 16.0 & 12.0 \\
\hline 比 & 成 & 長 & 価 & 5.30 & 7.05 & 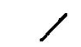 \\
\hline \multicolumn{4}{|c|}{ 好中球避走速度 $\mu / \mathrm{min}$} & 2.92 & 1.35 & ノ \\
\hline
\end{tabular}

No. 5

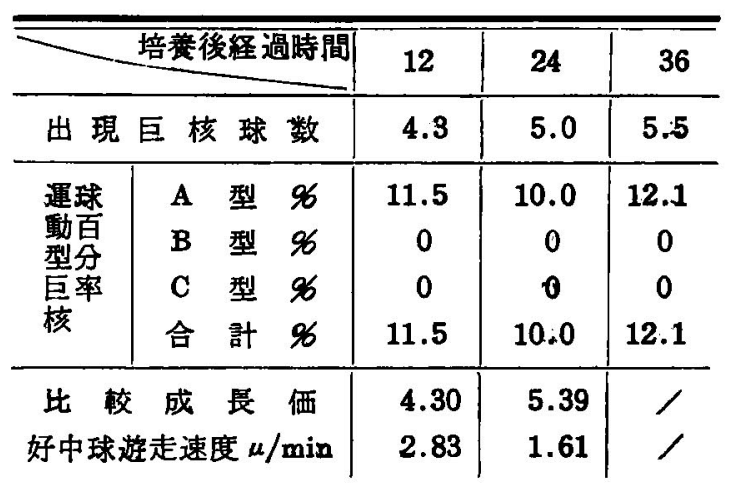

No. 6

\begin{tabular}{|c|c|c|c|c|c|}
\hline \multicolumn{3}{|c|}{ （培卷後経過時間 } & \multirow{2}{*}{$\frac{12}{8.3}$} & \multirow{2}{*}{$\frac{24}{7.4}$} & \multirow{2}{*}{$\begin{array}{r}36 \\
7.4\end{array}$} \\
\hline 出 現 & 巨核 球 & 数 & & & \\
\hline \multirow{4}{*}{$\begin{array}{l}\text { 運球 } \\
\text { 動百 } \\
\text { 型分 } \\
\text { 巨率 } \\
\text { 核 }\end{array}$} & A 型 & 96 & 3.6 & 5.4 & 6.7 \\
\hline & B 型 & $\%$ & 1.2 & 1.4 & 0 \\
\hline & C 型 & $\mathscr{6}$ & 1.2 & 0 & 0 \\
\hline & 合 計 & 96 & 6.0 & 6.7 & 6.7 \\
\hline & 成 長 & & 3.28 & 4.46 & $\nearrow$ \\
\hline \multicolumn{3}{|c|}{ 好中球遊走速度 $\mu / \mathrm{min}$} & 2.46 & 1.92 & $/$ \\
\hline
\end{tabular}

No. 7

\begin{tabular}{|c|c|c|c|c|c|}
\hline \multicolumn{3}{|c|}{ ( } & \multirow{2}{*}{$\frac{12}{5.0}$} & \multirow{2}{*}{$\frac{24}{5.0}$} & \multirow{2}{*}{$\begin{array}{r}36 \\
5.5\end{array}$} \\
\hline 出 現 & 巨核 球 & 数 & & & \\
\hline \multirow{4}{*}{$\begin{array}{l}\text { 罢球 } \\
\text { 皟 } \\
\text { 型分 } \\
\text { 巨䔞 } \\
\text { 核 }\end{array}$} & A 型 & $\not 6$ & 10.0 & 6.6 & 3.0 \\
\hline & B 型 & $\mathscr{6}$ & 0 & 3.3 & 0 \\
\hline & C 型 & $\mathscr{q}$ & 0 & 0 & 0 \\
\hline & 合 計 & $\mathscr{6}$ & 10.0 & 10.0 & 3.0 \\
\hline 比轎 & 成 長 & 価 & 4.60 & 5.33 & ノ \\
\hline \multicolumn{3}{|c|}{ 好中球逰走速度 $\mu / \min$} & 3.86 & 1.48 & ノ \\
\hline
\end{tabular}


No. 8

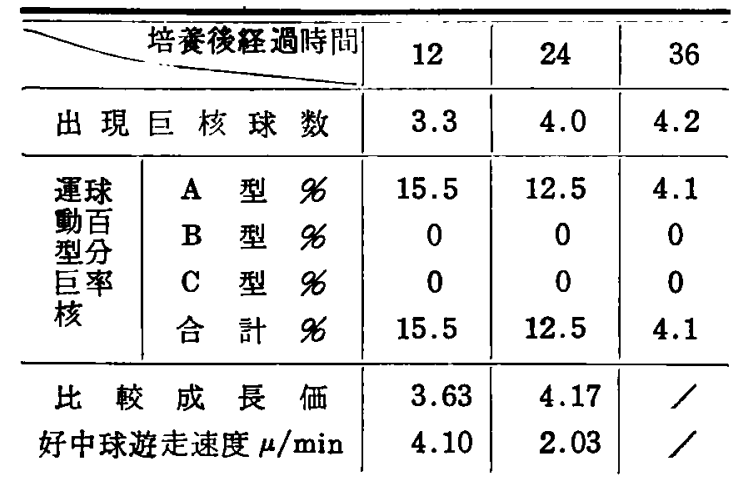

No. 9

\begin{tabular}{|c|c|c|c|c|c|c|}
\hline \multicolumn{4}{|c|}{ 培餥後経過時間| } & 12 & 24 & 36 \\
\hline \multicolumn{4}{|c|}{ 出 現 巨 核 球 数 } & 10.2 & 11.0 & 10.8 \\
\hline \multirow{4}{*}{$\begin{array}{l}\text { 運球 } \\
\text { 動百 } \\
\text { 型分 } \\
\text { 巨率 } \\
\text { 核 }\end{array}$} & & 型 & 96 & 3.9 & 7.3 & 5.5 \\
\hline & B & 型 & 96 & 1.9 & 0 & 0 \\
\hline & $\mathbf{C}$ & 型 & $\not 6$ & 0 & 0 & 0 \\
\hline & & 計 & $\mathscr{6}$ & 5.9 & 7.3 & 5.5 \\
\hline 比䡆 & 成 & 長 & 価 & 5.11 & 6.66 & $\gamma$ \\
\hline \multicolumn{4}{|c|}{ 好中球遊走速度 $\mu / \min$} & 3.10 & 2.44 & I \\
\hline
\end{tabular}

No. 10

\begin{tabular}{|c|c|c|c|c|c|c|}
\hline \multicolumn{4}{|c|}{ 一培羔後経過時間 } & \multirow{2}{*}{$\frac{12}{5.6}$} & \multirow{2}{*}{$\frac{24}{6.2}$} & \multirow{2}{*}{$\frac{36}{6.2}$} \\
\hline 出 晲 & 巨杉 & 球 & 数 & & & \\
\hline \multirow{4}{*}{$\begin{array}{l}\text { 運球 } \\
\text { 動百 } \\
\text { 型分 } \\
\text { 巨率 } \\
\text { 核 }\end{array}$} & $\mathbf{A}$ & 型 & $\%$ & 10.7 & 12.5 & 12.5 \\
\hline & B & 型 & 96 & 3.4 & 0 & 0 \\
\hline & $\mathrm{C}$ & 型 & $q 6$ & 0 & 0 & 0 \\
\hline & & 計 & 96 & 14.2 & 12.5 & 12.5 \\
\hline 此 & 成 & 芝 & 価 & 3.22 & 4.38 & $/$ \\
\hline 好中球 & e走速 & 度 $\mu$ & $\min$ & 3.33 & 1.37 & Y \\
\hline
\end{tabular}

表 $3^{\prime}$ No. 1 10 平均

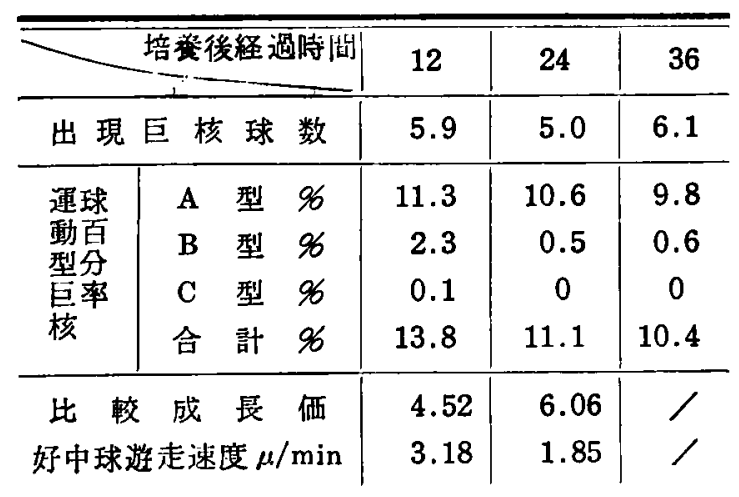

i）のそれの55.3\%に比し，著しく低值を示した. 培美24時開後では， $\mathrm{A}$ 型 $0 \sim 28.5 \%$, 平均10.6\%, $\mathrm{B}$ 型 $0 \sim 3.3 \%$ ，可均0.5\%，C 型は出現せす。，合計

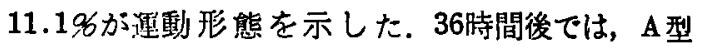
3.0 25.0\%, 平均 9.8\%, B 型 $0 \sim 6.6 \%$, 平均 $0.6 \% ， \mathrm{C}$ 型は出現せず，合計 $10.4 \% か ゙$ 運動形態を 示した.

次に組織增生の比較成長価を見るに，培䖯12時間 後3.22 6.24, 平均4.52, 24時間後 4.17 9.99, 平 均6.06であつた（四亚. 表亚”).

図 III比較成長価並びそ好中球遊走速度（海嗔） 好中球遊走速度

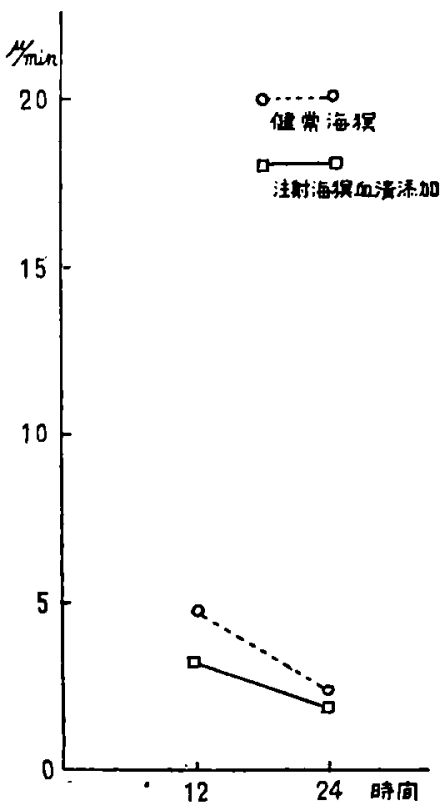

比較成長価

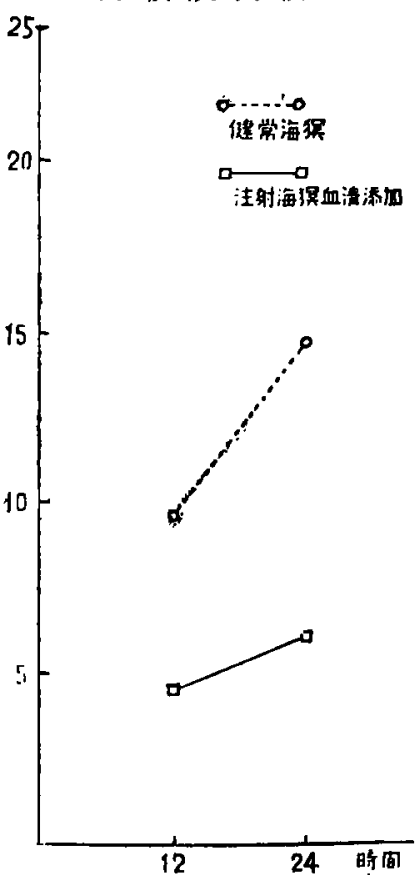


又増生帯に出現した好中球遊走速度は，培養12㭙 間後 2.46 4.10 $\mu / \mathrm{min}$, 平均 $3.18 \mu / \mathrm{min}$, 24時間 後 $1.35 \sim 2.55 \mu / \mathrm{min}$, 平均 $1.85 \mu / \mathrm{min}$ であつた (四II. 表政).

\section{第4章 総括並びに考按}

人の特発性栓球减少性紫轨病の栓球減少の成因を 解明する為，動物を用いてする実験は，従来多くの 学者か試みており，その実験方法も多蚑亘る。就 中動物䎲栓球減少症を発現せしめて，その病理 解明を，ての目的としたすのが多く見られる。 Ledingham ${ }^{54)}$ (1914）は，海䐎の栓球を分離し，之 を抗原として家兔を感作し，之より得られる抗海㩧 拴球血清を，健常海娦に再注射して，之に著明な出 血性素因，栓球减少を意起せしめ，注射部位のみな らず，遠隔部位にす出血を来さしめる事に成功した 更に Ledingham \& Bedson59)(1915) はこの事実の 始索を進め，1）抗拴球血清注射に上り栓球数か ～1/10亿著减する事，2）各種動物の抗栓球血清は 特異的であり，他種動物に注射してあ出血性素因を 発現させる事はない，3）末梢血液像に有核赤血球, 骨髄巨核球の出現した事を報告した。綿引(55)(1917) も同様の実験を行ない，抗栓球血清を皮下注射した 場合汇最す著明な出血性素因の発現, 栓球減少の起 る事を認め，注射部位附近に高度の出血性膯梯浸潤 を呈する他，溒隔部皮下にも出血斑が発生し，肺， 楊にる出血点の発生する事を証明した．その際の臓 器を䫓微鏡的に観察して, 出血機転を小血管壁内皮 緗胞の破填化求めんとした。 又 Bedson60)(1922) は，抗栓球血清が栓球を破壊するのみならず，赤血 球をも凝集せしめる事実を見出し，又出血機転を血 管壁の機械的な障碍によるむのとした，桂67)(1923) は，海犋の実颉的紫病に於りる出血機転は，抗栓 球血清の血管内皮細胞えの親和力之, 同血清による 恮球破填の相乗作用によつて血管内皮細胞が障碍さ れる為であるとし，拴球減少に基く血液性状の変化 は，出血に対する Bereitschaftをなすものであろ うとしている. 更に被験海犋の骨鋪巨核球に退行变 生のある事を認めた。川㙒56663)64)(1951，52）は，抗 海淇栓球血清による実験的栓球減少症の出血病理に つい, 詳細な顕微鏡的検索を試み，その機転を細 静脈よりする滤出性出血である事を確認した，同拣 の実稌伬田65666)(1951）高村67)(1951）等によつ ても行なわれ，何れも栓球減少，筀沫染色標本によ 万骨髄巨核球の栓球産生能低下，毛細血管抵抗減弱
等の事実のある事を証明している, 又一方, Spaet68) (1952), Dameshek69)(1932), Vulpis70)(1955) 等む 同様の実験をなし，之等は何れも，その出血性素因 の発現機序に関して，血清学的，免度学的機転を基 調とした発表を行なつている。

以上従来行なわれて来た研究の大部分は，抗栓球 血清を用いて実験的に栓球減少症を惹起せしめたと はいえ，現象そのもののみに病理的検索かなされて いるに過ぎない，又従来の研究の大部分か，血清学 的乃至免疫学的機転に上る血管采障碍又は血液成分 の変化を重視し，重要な因子である栓球减少に関し ては, 単にその崩壊乃至は，骨髄塗沫染色標本上に 於ける，骨㵦巨核球の退行変性程度にしか言及する あのがなかつた。教室岸71722)(1958）は，最近教室 て考案した簡易骨艏組織培養法を応用して，抗栓球 血清を用いて実験的栓球减少症を起させた海犋の， 骨髄を培湌し，その巨核球を観察した。即ち，出現 巨核球数では，健康のそれに比し，やや堌加を示し たが，その運動巨核球の百分率は，培養12時間後平 均 42.7\%,24時間後40.8\%であつて，健康海犋のそれ が, 62.3\%,61.8\%であるのに比し低值を示し, 就 中栓球産生能の盛んな触手状突起形成巨核球が，培 羡12時間後煡康海犋て $10.2 \%$, 注射海犋て $0.5 \%$ ， 24時間後健康海猽て11.4\%，注射海猽で $0.8 \%$ と, その減少が著しかつたとし，尚その際に組織増生並 びに好中球機能を観察し, 健常海猽之, 注射海犋の 間に有意の差は認めなかつたと述べている.

さて，抗栓球血清注射による，動物の実験的栓球 減少症, 及び人の特発性栓球減少性紫斑病に於いて, 著明な栓球減少, 出血時間の延長, 内部諸脿器への 出血及びそ㣗に因する二次的貧血等の事実を対照し て考える時，両者の出血機転及び栓球隇少の機転は， あるいは同一のあのではなかろうと思われる点が多 い. 先に私は，人の特発性栓球減少性柴斑病患者血 清中に，骨噵巨核球に直接作用して，その機能を減 弱せしめる因子の存在する事を，独自の方法で立証 したが，栓球减少を主徽とし，出血性素因を発現す るなど，之と臨休像の酷似する実験的栓球減少症動 物の血清中にす，単に栓球を破壊し，乃至は，血管 系に障碍を及ぼすのみならず，骨鹃道に直接作用する 因子の存在する事が想像される.人の特発性栓球減 少性柴斑病成因に関して，その血清中の催栓球隇少 性因子が論ぜられる以上，当然，実験的栓球减少症 動物血清につネても，同様の追求がなされるへきて ある、私の行なつた実験的栓球隇少症動物血清添加 


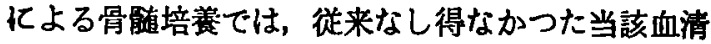
の，栓球母細胞である骨䯣巨校球えの直接影響を知 り得る点で, 実験的栓球减少症の成因を究明するに 当つて，最適な方法であると信ずる．即ち，侓常海 犋骨䯣を健常海猽血清中にて培羡すると，標本には， 培美12時閫後にして，増生带中に巨核球の出現を見， 胞体変形, 偽足形成, 触手状突起形成の三段階の運 動形態を明らかに認め得，且つ，偽足及び触手状突 起中には，顆柆の流㗢を，時に栓球分離の像の見ら れる事は，健康人の骨髄培養の場合と同様である.

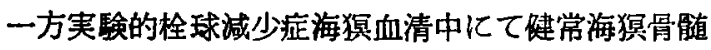
を培羡すると，増生帯に出現する巨核球数は，培羔後 $12,24,36$ 各時間後平均して, 5.9, 5.0,6.1個であつ て, 健康海猽血清中培養時の $5.5,5.7,5.8$ 個之比较 して，有意の差を認め得なかつた。 てれは，前編に 於ける人の特発性栓球減少性紫病患者血清添加培 養の際亡同様である. 然るに, 出現巨核球の内，運 動形汻を示するのを見ると，著しい差異が見られる。 即ち，培養12時間後では，平均13.8\%の巨核球に運 動形俧を認めるに過ぎず，乙れを健常海猽血清中培 羡の同時間後の平均55.396亿比すれは์，著しく低下 しているのが認められ，更に24時間後では平均 11.1

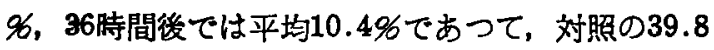
\%，28:4\%に比へて夫ネ，28.7\%，18.0\%の低下を 示している. 就中触手状突起形成巨核球は，培養12 時間後0.1\%（対照8.3\%）に過ぎす，24時間以後で は出現せず（対照ては，24時間後5.8\%，36時間後 2.9\%）又伪足形成巨核球も培善 $12,24,36$ 時間後 2.3 \%，0.5\%，0.6\%であつて，对照の17.7\%，12.1\%， 7.7\%に比して，著しく低下しているのが認められ 万. 斯くの如き，巨核球の機能低下は，培羡後の時 間の経過と共に，著明となり，培盖24時間後に到つ ては，殆んど全ての出現巨核球に北煇性顆粒，空泡 の出現 水泡形成，細胞の㜆化，胞体縁の鋸㐘状化， 舌状突起形成，核の渗縮等の変性像が著明に観察さ れ，触手状突起形成や，栓球分倠を示す巨核球は勿 論，偽足形成巨核球も殆んど見られず，僅かに，胞 体贸形巨核球が散見されるに過ぎい，乙の事実は， 已に多くの人達が実験的栓球減少症動物骨檤の程沫 標本淤いて観察し，又教室大河原18）が当該海狽 骨檤を組織培羡して，野態観察して得たと同様の所 見を示している。一方, 組織增生の比較成長価は, 培美12時間，24時間後，平均4.52，6.06であつて， 対照の日.78, 14.70に比し，低值を示しているか，增 生帯に出線した好中球の遊走速度は，培養 12,24
時間後平均 $3.18 \mu / \mathrm{min}, 1.85 \mu / \mathrm{min}$ て，対照の $4.74 \mu / \mathrm{min}, 2.28 \mu / \mathrm{min}$ と比較して, 有意の差異 が認められなかつた。

斯かる事実は，直接骨䯣化作用し，栓球産生能を 有する巨核球の機能を低下せしめる何等かの因子が， 実験的栓球减少性海猽の血清中に存在し，しかもそ れは，組織堌生をかなり抑制するが，好中球機能侣 は影響を与えないという事を示している.

教室岸71)72) は，抗栓球血清注射による実倹的栓 球减少症海犋骨髄を培盖して，その巨核球を钼察し た際，その機能低下は，人の特発性栓球减少性柴理 病畫者の巨核球機能低下に比し，軽度でるる述へ， 抗栓球血清注射では，人の特発性栓球減少性柴玨房 と全く同じ状態を作ることは，不可能であると述へ ている，比較的慢性に経過する人の場合と，急性に 経過する海猽の場合とを，全く同粎仅取うことは 危険であるが，人の特発性栓球減少性柴啀病の成因 として，その患者血清中に存在する巨核球機能減弱 因子が，最毛重要な役割を演じていると同様，实験的 栓球減少症動物の血清中にあ，巨核球機能を強く抑 制する因子が抗栓球血清注射により産生され，それ が実験的栓球減少症に於ける出血性素因の発現の一 端を担つているすのと考えられる。

\section{第 5 章 結論}

海䐎に抗栓球血清を注射して，実験的栓球減少症 を䓯起せしめ，その成因を追及する為に，簡易骨髄 組織培羕法を用いて, 健常海猽骨䯣を被注射海㩧血 清中で培羡し，増生帯に出現する巨核球数及びその 機能, 並び飞組織堌生の比校成長価，好中球遊走速 度を観察した。

1）増生帯に出現する巨核球数は，対照の健常海 犋血清中培誉の場合と，有意の差がなかつたが，そ の機能は対照に比し著しく低下し, 就中, 触手状突 起を形成し，栓球分離を示す巨核球の出現は，培養 24㭙間以後には全く見られず，又著明な変性像を認 めた。

2）比較成長価は，対照に比し低値を示した。

3）好中球遊走速度は，対照との間敒有意の差を 認めなかつた。

以上により，実䀦的栓球減少症海㺅血清中には， 直接胃膸巨核球作用して，その栓球座生を抑制す る因子が存在する事を知つた。 
擱筆するにあたり御懇篤なる御指導と御校閲を睗 わつた恩師平木教授並びに角南講師に深甚なる謝意 を表する.
（本墖文の要旨は, 第19回日本血液学会総会飞於 いて発表した.)

\title{
Clinical and Experimental Studies on the Characteristics of Idiopathic Thrombocytopenic Purpura
}

\section{Part 2 The Influence of the Serum of Guinea Pigs with Experimental Thrombocytopenia on the Megakaryocyte Function}

By

\author{
Seiken Honda \\ Department of Internal Medicine Okayama University Medical School \\ (Director : Prof. Kiyoshi Hiraki)
}

With a view to study the causative factor of the experimental thrombocytopenia induced in guinea pigs by injecting anti-platelet serum into guinea pigs, the author performed the bone-marrow tissue culture of normal guinea pigs in the serum of guinea pigs with this experimental thrombocytopenia by means of the simple method of bone-marrow tissue culture, and observed the number and functions of megakaryocytes as well as the relative tissue growth rate and the wandering velocity of neutrcphils.

The number of megakaryocytes appearing in the tissue growth area showed no significant difference from that of the bone-marrow tissue culture in the serum of normal guinea pigs, the control, but the megakaryocyte function was markedly diminished as compared with the control, especially after 24 hours' culture no such megakaryocytes as showing the separation of platelets could at all be observed and also a marked degenerative picture was observed.

The relative tissue growth rate was somewhat decreased, and the wandering velocity of neutrophils showed no significant difference from that of the control.

From these findings it has become clear that in the serum of guinea pigs with experimental thrombocytopenia there exists a factor acting directly on megakarxocytes as to suppress the separation of platelets. 